Науковий вісник НлтУ України
Scientific Bulletin of UNFU
http://nv.nltu.edu.ua $\begin{array}{r}\text { CC) (i) ISSN 1994-7836 (print) } \\ \text { ISSN 2519-2477 (online) } \\ \begin{array}{l}\text { https://doi.org/10.15421/40290408 } \\ \text { Article received 20.03.2019 p. } \\ \text { Article accepted 25.04.2019 p. } \\ \text { Удк 339.187.44:368(447) }\end{array} \\ \begin{array}{l}\text { K. P. Danylkiv } \\ \text { krisdanko@ukr.net }\end{array} \\ \hline\end{array}$

Х. П. Данилків, Х. В. Горбова

Національний університет "Львівська політехніка", м. Львів, Украӥна

\title{
ДОСЛІДЖЕННЯ ЯКОСТІ СТРАХОВОГО ПОРТФЕЛЯ АСК "ІНГО УКРАЇНА"
}

Страхові компанії відіграють провідну роль у становленні та подальшому розвитку країн з перехідною економікою, їхня спроможність нівелювати різні несприятливі події, а також бути активними інвесторами на фінансовому ринку стимулюють трансформаційні процеси в економіці. Водночас ефективне функціонування самих страхових компаній забезпечується реалізацією значної кількості управлінських процесів, базовим з яких є формування оптимального страхового портфеля. У сучасних умовах завдання управління страховим портфелем актуалізується передусім унаслідок появи ризиків, зумовлених розвитком інформаційних технологій і автоматизованих систем управління, а також ризиків, що виникають внаслідок трансформаційних тенденцій щодо конвергенції та інтеграції сегментів фінансового ринку, раніше не пов'язаних між собою. Окрім цього, потребу дослідження питань щодо управління страховим портфелем зумовлюється появою нових інструментів мінімізації ризиків, що дають змогу змінювати підходи до формування страхового портфеля, включаючи в нього більше спеціалізованих і масштабних ризиків без загрози втрати платоспроможності компанії. 3 урахуванням сучасних тенденцій розвитку фінансового ринку, зокрема його трансформації, під впливом глобалізаційних процесів виникає об'єктивна потребу у розвитку та вдосконаленні підходів до управління страховим портфелем страхових компаній. Досліджено теоретичні засади управління якістю страховим портфелем та обгрунтовано підходи до формування оптимального страхового портфеля 3 урахування заданого рівня ризику та прибутковості, що є однією з умов забезпечення фінансової стійкості страховика. Проаналізовано структуру страхового портфеля ПрАТ АСК "ІНГО Україна" і оцінено його збалансованість. Визначено, що страхова компанія має високу прибутковість та досить низьку ризиковість.

Ключові слова: страхова компанія; страхові премії і виплати; страхування; надходження; ризики.

Вступ. Інтенсивний розвиток страхування у світі зумовлює зростання масштабів діяльності страхових компаній та підвищену увагу до питань формування збалансованого страхового портфеля. В умовах ринкової економіки страхові компанії, як об'єкти управління, володіють як загальними, так і специфічними властивостями. Специфічність їх діяльності полягає в наданні властивих тільки страховикам послуг, у наданні страхового захисту. Пропонуючи такі послуги, страхові компанії повинні постійно здійснювати моніторинг проваджуваної страхової діяльності, зокрема особливу увагу мають приділяти формуванню і збалансуванню страхового портфеля, адже від його якості, величини, структури та динаміки залежать надходження страхових платежів, розмір і коливання виплат страхового відшкодування і страхових сум (Val, \& Chubatiuk, 2018; Zhuravka, 2012).

Сучасна страхова наука виявляе помітну цікавість до теоретичної концептуалізації та специфіки формування і управління страховим портфелем. Як відомо, сьогодні ринок страхування потребує високої корпоративної культури страхових компаній та вміння не тільки приймати страхові зобов'язання, а й обов'язково їх виконувати. При цьому одним із важливих чинників, який впливає на успішний розвиток страхових компаній, $є$ застосування науково обгрунтованих підходів до формування та управління страховим портфелем.

Обговорення отриманих результатів. У поточній та в подальшій перспективній діяльності будь-якої страхової компанії визначальним чинником $є$ її страховий портфель. Це обгрунтовано тим, що від кількісних та якісних характеристик страхового портфеля (рис. 1) залежать обсяги страхових премій і страхових виплат, які формують основні вхідні та вихідні грошові потоки страховика, інвестиційні можливості страхової організації, величину і склад його страхових резервів, розмір iї витрат на ведення справи, фінансові результати, а також ринкова вартість страхової компанії. 3 огляду на зазначене вище очевидно - на скільки важливо для страхової компанії забезпечити збалансованість ії страхового портфеля та підтримувати цю характеристику впродовж тривалого періоду.

Структуру та якість страхового портфеля можна аналізувати за допомогою певних показників. Відповідна його величина виражається або кількістю застрахованих об'єктів, або загальною страховою сумою (тобто обсягом страхової відповідальності).

Для структури страхового портфеля властиве спів-

Інформація про авторів:

Данилків Христина Петрівна, канд. екон. наук, ст. викладач, кафедра фінансів, обліку і аналізу. Email: krisdanko@ukr.net; https://orcid.org/0000-0003-1283-6844

Горбова Христина Володимирівна, канд. екон. наук, доцент, кафедра фінансів, обліку і аналізу. Email: gorbova_kristina@ukr.net; https://orcid.org/0000-0001-7826-5728

Цитування за ДСтУ: Данилків Х. П., Горбова Х. В. Дослідження якості страхового портфеля АСК "Інго Україна". Науковий вісник НЛТУ України. 2019, т. 29, № 4. С. 42-46.

Citation APA: Danylkiv, K. P., \& Gorbova, K. V. (2019). The study of the quality of the insurance portfolio of Ingo Ukraine JSIC. Scientific Bulletin of UNFU, 29(4), 42-46. https://doi.org/10.15421/40290408 
відношення окремих видів страхування - між обов'язковими й добровільними формами. Відповідно таку структуру страхового портфеля можна аналізувати в аспекті питомої ваги чинних страхових договорів і знову укладених договорів 3 низькими (мінімальними) і високими (максимальними) сумами, групових та індивідуальних страхувань. Структура страхового портфеля складається з системи видів і форм страхування, тобто під впливом асортименту страхових послуг. Особливе значення для забезпечення фінансової сталості страхових операцій має оперативне реагування на задоволен-

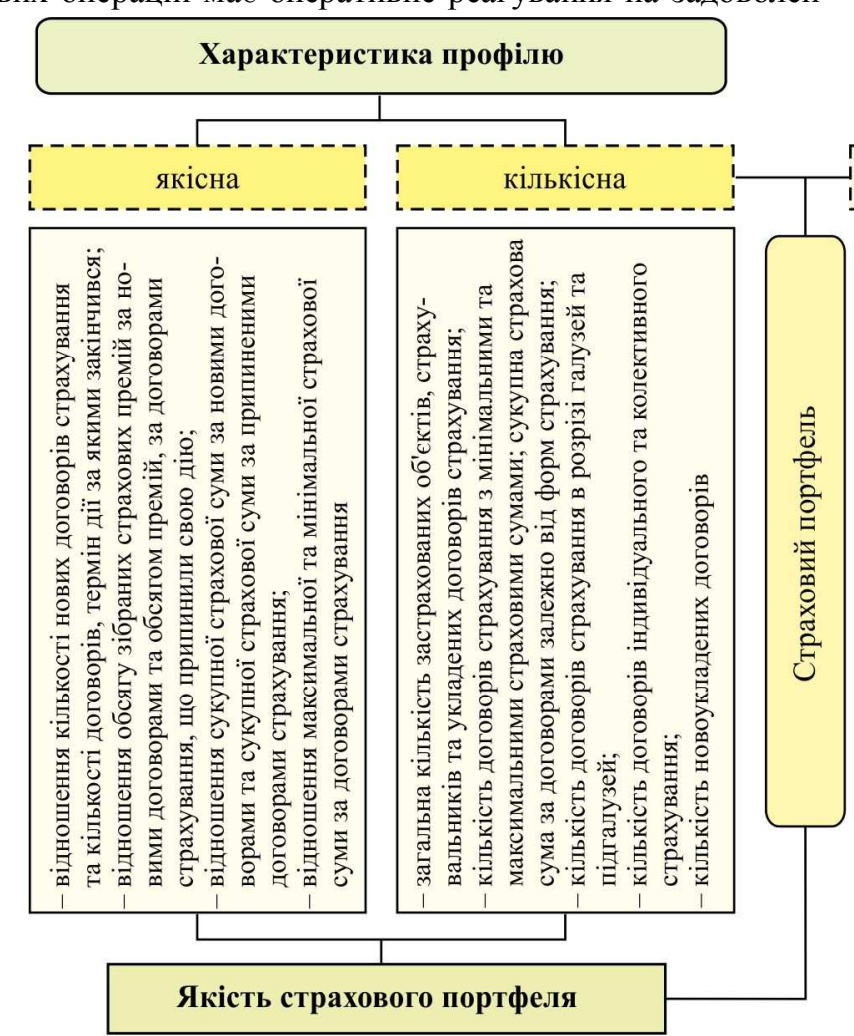

Рис. 1. Концептуальна схема формування страхового портфеля

Величину та структуру страхового портфеля характеризують цілі та завдання страхової компанії на ринку, перелік страхових послуг, які нею надаються. Будь-яка страхова компанія намагається певним чином впливати на величину та структуру власного страхового портфеля 3 метою отримання бажаних якісних показників своєї діяльності, втілених у кінцевому результаті- у прибутку (Baranov, 2006, p. 37). Управління страховим портфелем дає змогу своєчасно реагувати на зміни як зовнішнього середовища, так і внутрішнього стану страховика і формувати збалансований якісний страховий портфель як основу стабільного фінансового положення страхової компанії (Pikus, \& Balytska, 2016; Sosnovska, 2017).

Інструменти оптимізації страхового портфеля страхової компанії в сучасних умовах наведено на рис. 2.

3 метою зміцнення фінансового становища страхової компанії необхідно розвивати менш збиткові види страхування, коригуючи тарифну політику, розвиваючи регіональну мережу, реалізуючи програми лояльності відносно клієнтів - фізичних осіб, що особливо актуально в умовах зниження платоспроможності населення. Основні фінансові показники, що характеризують результати діяльності ПрАТ АСК "ІНГО Україна", наведено у табл. 1. ня попиту в тих страхових послугах, які в ринкових умовах відповідають інтересам страхувальників (Zhuravka, 2012; Strakhovyi rynok, 2019).

Важливу увагу необхідно звертати на динамічність страхового портфеля, що характеризується співвідношенням між страховими договорами, що вже закінчуються, та страховими договорами, які знову укладаються. Необхідно зазначити, що важливою є рівновага портфеля, тобто рівність між тими страховими договорами, які уклались, та тими, термін дії яких закінчився (Derzhavna komisiia, 2019; Pikus, \& Balytska, 2016).

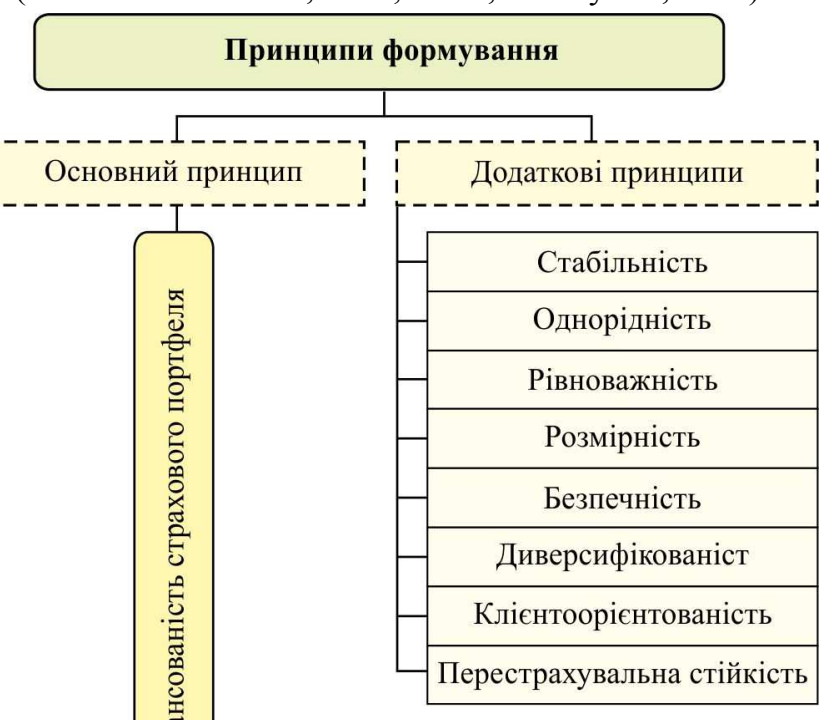

Табл. 1. Фінансові показники ПрАТ АСК "ІНГО Україна"

\begin{tabular}{|c|c|c|c|c|c|}
\hline \multirow{2}{*}{$\begin{array}{c}\text { Фінансовий } \\
\text { показник }\end{array}$} & 2014 р. & 2015 р. & $\begin{array}{c}\text { Динаміка за } \\
2014 / 2015 \text { рp. }\end{array}$ & 2016 p. & 2017 p. \\
\cline { 2 - 6 } & $\begin{array}{c}\text { млн } \\
\text { грн }\end{array}$ & $\begin{array}{c}\text { млн } \\
\text { грн }\end{array}$ & $+/-, \%$ & $\begin{array}{c}\text { млн } \\
\text { грн }\end{array}$ & $+/-$, \\
\hline Активи & 1173,2 & 1297,1 & $+10,6$ & 1813 & $+21,0$ \\
\hline $\begin{array}{c}\text { Страхові } \\
\text { премії }\end{array}$ & 766,5 & 766,5 & $+31,9$ & 903,4 & $+17,8$ \\
\hline $\begin{array}{c}\text { Страхові } \\
\text { резерви }\end{array}$ & 553,1 & 567,2 & $+2,6$ & 788 & $+16,2$ \\
\hline $\begin{array}{c}\text { Власний ка- } \\
\text { пітал }\end{array}$ & 439,3 & 536,6 & $+22,1$ & 641 & $+4,6$ \\
\hline $\begin{array}{c}\text { Страхові } \\
\text { виплати }\end{array}$ & 291,4 & 452,9 & $+55,4$ & 550 & $+49,2$ \\
\hline
\end{tabular}

Протягом 2015 р. ПрАТ АСК "ІНГО Україна" зібрала понад ніж 766 млн грн страхових премій, що майже на $32 \%$ більше від показника 2014 р. При цьому чистий прибуток зріс на 31,3 \% - до 73,5 млн грн. За обсягами премій Компанія входить до десятки лідерів ринку. Обсяг страхових виплат протягом року зріс більш ніж на $55,4 \%$ і становить 452,9 млн грн.

За період 2016-2017 pр. фінансові показники ПрАТ АСК "ІНГО Україна" демонстрували позитивну динаміку росту. Вартість чистих активів Товариства на 31.12.2017 р. становить 640996,4 тис. грн Структура активів Товариства має такий вигляд: 56 \% ліквідні активи у формі грошей, депозитів та ОВДП, 24 \% - права 
вимоги до перестраховиків, $16 \%$ - нерухоме майно, $4 \%$ - акції дочірньої компанії. Перевищення чистих активів над величиною статутного капіталу становить 335453,4 тис. грн Станом на 31.12 .2017 р. фактичний запас платоспроможності становить 616416,6 тис. грн, що перевищує нормативний запас платоспроможності на суму 452053,6 тис. грн.

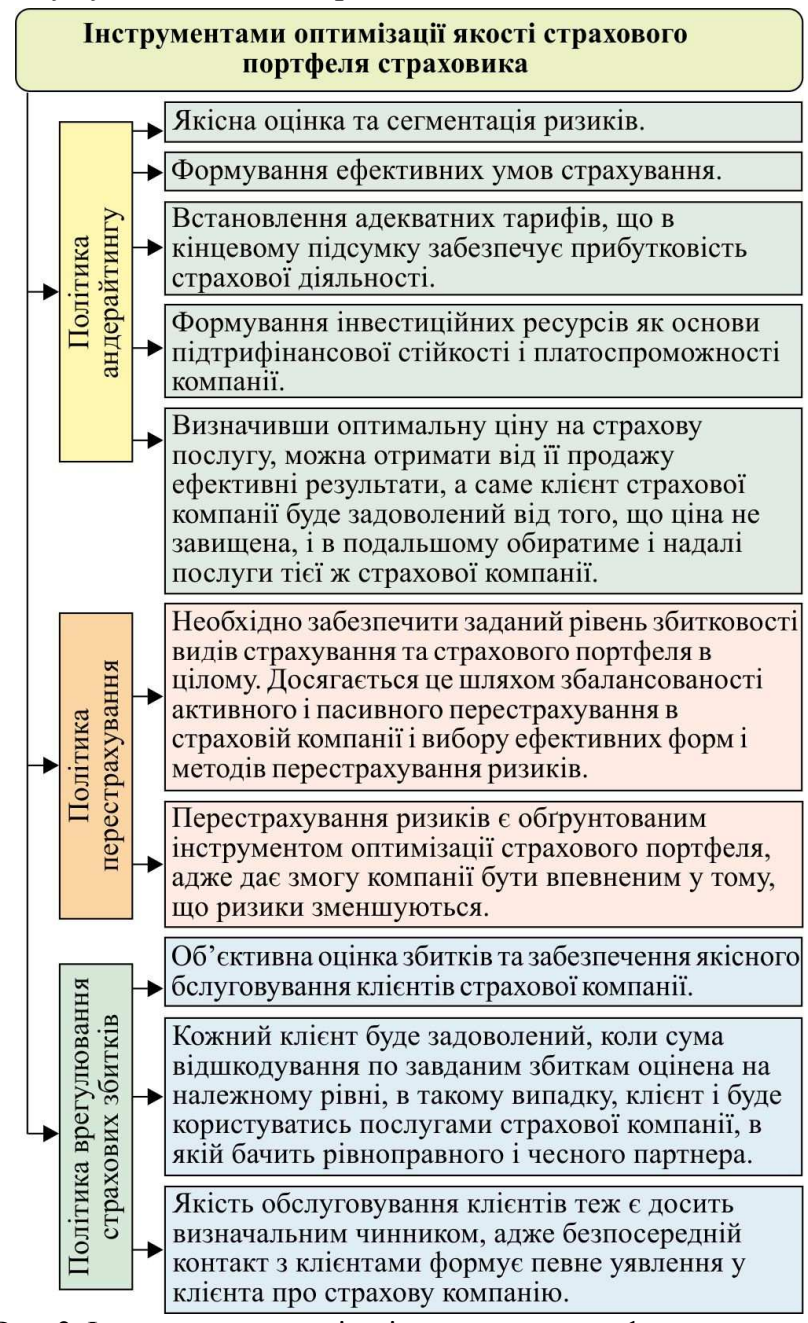

Рис. 2. Інструменти оптимізації страхового портфеля страхових компаній в сучасних умовах

Власний капітал компанії збільшився майже на 5 \%, тобто на 641 млн грн. 3 огляду на динаміку прибуткового зросту, за підсумками 2017 р., активи компанії зросли до 1,813 млрд грн, що на $21 \%$ більше, ніж у 2016 р. При цьому компанія витримує всі нормативи стосовно ліквідності активів. На 31.12.2017 р. фактичний запас платоспроможності становить 616,4 млн грн, що перевищує нормативний показник на $275 \%$ (Derzhavna komisiia, 2019; INHO Ukraina, 2019).

За своїми зобов'язаннями перед клієнтами у 2017 р. компанія виплатила понад 540 млн грн (що майже на 50 \% більше) і врегулювала понад 86 тис. страхових подій. Сформовані резерви на кінець року становлять 787 млн грн. Компанія успішно працює як з роздрібни-

Табл. 2. Динаміка та структура надходжень від операційної діяльності ПрАТ АСК "ІНГО Україна" за період $2015-2017$ рр.

\begin{tabular}{|c|c|c|c|c|c|c|c|}
\hline \multirow{3}{*}{ Вид страхування } & \multirow{2}{*}{2015 p. } & \multirow{2}{*}{2016 p. } & \multirow{2}{*}{2017 p. } & \multicolumn{4}{|c|}{ Відхилення } \\
\hline & & & & \multicolumn{2}{|c|}{ абсолютне, +/- } & \multicolumn{2}{|c|}{ відносне, \% } \\
\hline & & млн грн & & $2016 / 2015$ pp. & $2017 / 2016$ pp. & $2016 / 2015$ pp. & $2017 / 2016 \mathrm{pp}$. \\
\hline Транспортне страхування & 408,62 & 485,4 & 496 & 76,78 & 10,60 & $-15,82$ & $-2,14$ \\
\hline $\begin{array}{l}\text { Комплексне страхування } \\
\text { відповідальності та майна }\end{array}$ & 251 & 755488 & 1013956 & 755237,00 & 258468,00 & $-99,97$ & 25,49 \\
\hline Особисті види страхування & 107,95 & 147961 & 148295 & 147853,05 & 334,00 & $-99,93$ & 0,23 \\
\hline
\end{tabular}

ми клієнтами, так і з корпоративним сектором, завдяки чому зберігає збалансований портфель страхових премій. Протягом 2017 р. було укладено понад 296 тис. договорів страхування, 3 них із фізичними особами 176 тис., із юридичними - 120 тис. договорів.

Аналіз страхового портфеля проводиться в динаміці, де його основними показниками є величина страхового портфеля і його структура. Проте страховий портфель можна аналізувати 3 позицій кількісних характеристик - за обсягами зібраних страхових премій та обсягами, здійснених страхових виплат, а також $з$ якісної сторони - визначаючи рівень виплат, тобто збитковість страхового портфеля.

Проаналізовано динаміку та структуру надходжень страхових премій ПрАТ АСК "ІНГО Україна" за період 2015-2017 рр. (табл. 2).

Згідно з результатами діяльності, за 2017 р. нараховано страхових премій 1064474,0 тис. грн, за аналогічний період 2016 р. цей показник становив 903448,7 тис. грн, у тому числі за видами страхування: на транспортне страхування припадає 496 млн грн; на комплексне страхування відповідальності та майна - понад 1013956 млн грн; на особисті види страхування 148295 млн грн. Докладні дані про надходженням від транспортного страхування подано в табл. 3 .

Позитивну динаміку зростання надходжень від транспортного страхування пояснюємо насамперед підвищенням попиту на послуги компанії щодо страхування автомобілів, який викликаний політикою компанії в наданні страхових послуг із страхування автомобілів на вигідних умовах для страхувальника, а також постійним збільшенням кількості автовласників. Про збільшення попиту на послуги із страхування автомобілів також свідчить той факт, що надходження за полісами КАСКО займають більшу частину надходжень від транспортного страхування $(256,17$ млн грн у 2015 р., 301,4 млн грн у 2016 р., 960,0 млн грн у 2017 р.) і при цьому відбувається поступове їхнє зростання (на $318,51 \%$ у 2017 р., порівняно з 2016 р., та на 117,66 \% у 2016 р., порівняно з 2015 р.).

Друге місце за обсягами надходжень посідає комплексне страхування відповідальності та майна (табл. 4). Як бачимо ПрАТ АСК "ІНГО Україна" протягом 2017 р. збільшила обсяг зібраних премій у комплексному страхуванні до 421,8 млн грн, порівняно 3 251 млн грн у 2015 р. Премії зросли за рахунок страхування спеціальних ризиків (46,6 млн грн у 2015 р., 53,3 млн грн у 2016 р. та 57,2 млн грн у 2017 р.), добровільного страхування цивільної відповідальності перед третіми особами (22,8 млн грн у 2015 р., 27,9 млн грн у 2016 р. та 34,7 млн грн у 2017 р.), відповідальності операторів ядерної установки (24,4 млн грн у 2015 р., 13,3 млн грн у 2016 р. та 11,5 млн грн у 2017 р.) та страхування фінансових ризиків (34,9 млн грн у 2015 р., 26 млн грн у 2016 р. та 24 млн грн у 2017 р.). 
Табл. 3. Динаміка та структура надходжень від транспортного страхування ПрАТ АСК "ІНГО Україна" за період 2015-2017 рp.

\begin{tabular}{|c|c|c|c|c|c|c|c|}
\hline \multirow{3}{*}{ Вид страхування } & \multirow{2}{*}{2015 p. } & \multirow{2}{*}{2016 p. } & \multirow{2}{*}{2017 p. } & \multicolumn{4}{|c|}{ Відхилення } \\
\hline & & & & \multicolumn{2}{|c|}{ абсолютне, $+/-$} & \multicolumn{2}{|c|}{ відносне, \% } \\
\hline & & мЛн грг & & 2016/2015 pp. & 2017/2016 pp. & 2016/2015 pp. & 2017/2016 pp. \\
\hline Автокаско & 256,17 & 301,4 & 960,0 & 45,23 & 658,60 & $-15,01$ & $-68,60$ \\
\hline ОСЦПВ & 45,16 & 48,9 & 220 & 3,74 & 171,10 & $-7,65$ & $-77,77$ \\
\hline "Зелена картка" & 96,03 & 130,1 & 134,7 & 34,07 & 4,60 & 35,48 & 3,54 \\
\hline $\begin{array}{l}\text { ДЦВ та ДЦВ та страхування від НВ } \\
\text { на транспорті страхування від НВ на } \\
\text { транспорті }\end{array}$ & 11,26 & 12,34 & 18,0 & 1,08 & 5,66 & $-8,75$ & $-31,44$ \\
\hline Транспортне страхування, усього & 408,62 & 492,74 & 1134,7 & 84,12 & 641,96 & $-17,07$ & $-56,58$ \\
\hline
\end{tabular}

Табл. 4. Динаміка та структура надходжень комплексного страхування відповідальності та майна ПрАТ АСК "ІНГО Україна" за період 2015-2017 рp.

\begin{tabular}{|c|c|c|c|c|c|c|c|}
\hline \multirow{3}{*}{ Вид страхування } & \multirow{2}{*}{$2015 \mathrm{p}$} & \multirow{2}{*}{$2016 \mathrm{p}}$. & \multirow{2}{*}{$2017 \mathrm{p}$. } & \multicolumn{4}{|c|}{ Відхилення } \\
\hline & & & & \multicolumn{2}{|c|}{ абсолютне, +/- } & \multicolumn{2}{|c|}{ відносне, \% } \\
\hline & & мЛн грг & & $2016 / 2015$ pp. & $2017 / 2016$ pp. & $2016 / 2015$ pp. & $2017 / 2016$ pp. \\
\hline Страхування майна & 83,5 & 101,4 & 244,5 & 17,90 & 143,10 & $-17,65$ & $-58,53$ \\
\hline Страхування вантажів & 15,2 & 23,5 & 46,6 & 8,30 & 23,10 & $-35,32$ & $-49,57$ \\
\hline $\begin{array}{l}\text { Страхування ЦВ операторів ядерної ус- } \\
\text { тановки }\end{array}$ & 24,4 & 13,3 & 11,5 & $-11,10$ & $-1,80$ & $-45,49$ & $-13,53$ \\
\hline Страхування фінансових ризиків & 34,9 & 26 & 24 & $-8,90$ & $-2,00$ & 34,23 & 8,33 \\
\hline $\begin{array}{l}\text { Добровільне страхування ЦВ перед } \\
\text { третіми особами }\end{array}$ & 22,8 & 27,9 & 34,7 & 5,10 & 6,80 & $-18,28$ & $-19,60$ \\
\hline $\begin{array}{l}\text { Добровільне страхування сільськогос- } \\
\text { подарської продукції }\end{array}$ & 22,1 & 21,6 & 60,0 & $-0,50$ & $-21,00$ & 2,31 & 3500,00 \\
\hline Страхування спеціальних ризиків & 46,6 & 53,3 & 57,2 & 6,70 & 3,90 & 14,38 & 7,32 \\
\hline Інше & 1,5 & 2,3 & 2,7 & 0,80 & 0,40 & $-34,78$ & $-14,81$ \\
\hline $\begin{array}{l}\text { Комплексне страхування майна та від- } \\
\text { повідальності, усього }\end{array}$ & 251 & 216,9 & 421,8 & $-34,10$ & 204,90 & 15,72 & $-48,58$ \\
\hline
\end{tabular}

ПрАТ АСК "ІНГО Україна" збільшила обсяг зібраних страхових премій одразу з декількох видів страхування спеціальних ризиків. Зокрема в авіастрахуванні за останній рік портфель премій зріс до 29,3 млн грн. Із них 28,2 млн грн зібрано в обов'язковому страхуванні цивільної авіації та 1 млн грн - у добровільному страхуванні відповідальності власників повітряного транспорту. ПрАТ АСК "ІНГО Україна" у добровільному страхуванні водного транспорту займає $21,8 \%$ ринку 3 портфелем зібраних премій у 4,6 млн грн.

На останньому місці за надходженнями страхового портфеля - надходження від особистого страхування, при цьому, як і у випадку з комплексним страхуванням відповідальності та майна та транспортним страхуванням, спостерігаємо позитивну тенденцію до зростання Табл. 5. Динаміка та структура надходжень від особистого страх надходжень від особистого страхування. Докладну дані про надходження від особистого страхування ПрАТ АСК "ІНГО Україна" подано в табл. 5. У 2016 р. ПрАТ АСК "ІНГО Україна" зміцнила свої позиції в сегменті особистого страхування. У добровільному медичному страхуванні (ДМС) обсяги зібраних премій зросли більше ніж на $33 \%$ - до 125,5 млн грн. Така динаміка у понад 5 разів перевищує середню на ринку. Близько $19 \%$ премій у ДМС надійшли завдяки співпраці з міжнародним пулом Generali Employee Benefits (GEB). У страхуванні подорожуючих кількість страхових полісів ПрАТ АСК "ІНГО Україна" для подорожуючих осіб за кордон збільшилися на $20 \%$, перевищивши 54 тис. Рівень виплат компанії у цьому сегменті становив майже $65 \%$, що на $33,5 \%$ перевищує середній показник на ринку.

\begin{tabular}{|c|c|c|c|c|c|c|c|}
\hline \multirow{3}{*}{ Вид страхування } & \multirow{2}{*}{2015 p. } & \multirow{2}{*}{$2016 \mathrm{p}$} & \multirow{3}{*}{2017 p. } & \multicolumn{4}{|c|}{ Відхилення } \\
\hline & & & & \multicolumn{2}{|c|}{ абсолютне, +/- } & \multicolumn{2}{|c|}{ відносне, \% } \\
\hline & & млн грн & & $2016 / 2015$ pp. & 2017/2016 pp. & $2016 / 2015$ pp. & $2017 / 2016 \mathrm{pp}$. \\
\hline Страхування подорожуючих & 11,63 & 125,5 & 80,0 & 113,87 & $-45,50$ & $-90,73$ & 56,88 \\
\hline Добровільне медичне страхування & 94,05 & 15,3 & 48,6 & $-78,75$ & 33,30 & 514,71 & $-68,52$ \\
\hline Страхування від нещасного випадку & 2,27 & 4,7 & 1,0 & 2,43 & $-3,70$ & 107,05 & $-78,72$ \\
\hline
\end{tabular}

Найбільшу частку з виплат за страховими випадками займає автострахування (206,2 млн грн у 2015 р., 233,3 млн грн у 2016 p., 328,3 млн грн у 2017 р.), при чому його питома вага стрімко зростає (на $113,14 \%$ у 2016 р., порівняно з 2015 р., та на 140,72 \% у 2017 р., порівняно $з 2016$ р.).

Найбільшу частку з виплат за страховими випадками займає авто КАСКО - 218,7 млн грн у 2017 р., при чому його питома вага зростає. Найменшу частку з виплат займає страхування від нещасних випадків 0,6 млн грн у 2017 р. Страхова компанія ПрАТ АСК "ІНГО Україна" здійснює страхові виплати у разі настання страхових випадків, визначених у договорі страхування. Це дає нам можливість проаналізувати і зазначену характеристику страхового портфеля. А це допомагає зробити висновки щодо ефективності чи неефек- тивності діяльності страхової компанії з позицій оптимальності та збалансованості страхового портфеля.

Отже, страховий портфель компанії за надходженнями страхових премій поступово зростає. Також зростають обсяги надходжень майже від усіх страхових послуг, які надає компанія. При цьому спостерігаємо спрямованість і навіть спеціалізацію компанії на наданні послуг з автострахування.

Висновки. Одним із чинників забезпечення фінансової сталості страхової компанії є формування збалансованого страхового портфеля. Базовим або основним принципом формування страхового портфеля $є$ принцип збалансованості, досягнення якого можливе тільки за умови дотримання комплексу додаткових принципів, а саме: стабільності, однорідності, рівноважності, розмірності, перестрахувальної стійкості, безпечності, ди- 
версифікованості та клієнтоорієнтованості. При цьому характеристика профілю страхового портфеля компанії можлива $з$ огляду на кількісні та якісні індикатори, що даватиме змогу досліджувати якість страхового портфеля та вчасно вживати комплекс заходів із його стабілізації та підтримання на заданому рівні з урахуванням зовнішніх і внутрішніх чинників.

Аналіз портфеля страхової компанії ПрАТ АСК "IHГО Україна" дав змогу зробити такі висновки:

Страховий портфель страхової компанії ПрАТ АСК "ІНГО Україна" є збалансованим та оптимальним з високим рівнем прибутковості та з низьким рівнем ризику.

Портфель особистого страхування страхової компанії ПрАТ АСК "ІНГО Україна" можна вважати однорідним і таким, що належить до класичного типу. Внаслідок цього доцільним буде пасивне управління, яке передбачає створення добре диверсифікованого страхового портфеля з визначеним рівнем ризику, розрахованим на тривалу перспективу.

\section{Перелік використаних джерел}

Baranov, A. (2006). Teoretychni zasady upravlinnia strakhovym portfelem. Rynok tsinnykh paperiv, 3-4, 35-38. [In Ukrainian].
Val, A. M., \& Chubatiuk, V. M. (2018). Sposoby upravlinnia strakhovym portfelem. Retrieved from: http://intkonf.org/val-am-ktnchubatyuk-vm-sposobi-upravlinnya-strahovim-portfelem/. [In Ukrainian].

Zhuravka, O. S. (2012). Teoretychni osnovy formuvannia strakhovoho portfelia. Biznesinform, 5, 201-204. [In Ukrainian].

Strakhovyi rynok. (2019). Informatsiia pro stan i rozvytok strakhovoho rynku Ukrainy. Retrieved from: https://www.nfp.gov.ua/ua/ Informatsiia-pro-stan-i-rozvytok-strakhovoho-rynku-Ukrainy.html. [In Ukrainian].

Derzhavna komisiia. (2019). Ofitsiinyi sait Derzhavnoi komisii z rehuliuvannia rynkiv finansovykh posluh Ukrainy. Rozdil "Strakhovyi rynok". Retrieved from: http://www.dfp.gov.ua/732.html. [In Ukrainian].

INHO Ukraina. (2019). Ofitsiinyi sait kompanii "INHO Ukraina". Retrieved from: http://www.ingo.ua/. [In Ukrainian].

Pikus, R. V., \& Balytska, M. V. (2016). Finansova stiikist strakhovoi orhanizatsii ta dzherela yii zabezpechennia. Visnyk Kyivskoho natsionalnoho universytetu im. Tarasa Shevchenka, 3(180), 6-10. [In Ukrainian].

Sosnovska, O. O. (2017). Elementy zabezpechennia finansovoi stiikosti strakhovykh kompanii. Ekonomika, finansy i upravlinnia $v$ XXI stolitti: analiz tendentsii ta perspektyvy rozvytku: Zbirnyk tez mizhnarodnoi naukovo-praktychnoi konferentsii (pp. 70-74). [In Ukrainian].

\section{THE STUDY OF THE QUALITY OF THE INSURANCE PORTFOLIO OF INGO UKRAINE JSIC}

The insight of the necessity to balance the insurance portfolio becomes especially relevant, since the insurance portfolio is the basis for all the insurance activities and which determines the financial stability of the insurance company in general. The size, quality, structure and dynamics of the insurance portfolio depend on the receipt of insurance payments, the amount and fluctuations of insurance indemnity payments and insurance amounts, and also the profitability of insurance operations. The goal of optimizing a portfolio is to determine what portion of the portfolio should be allocated for each type of insurance so that the size of the expected income and the level of risk optimally match the goals of the insurance organization. The purpose of the article is to study the quality of the insurance portfolio of INGO Ukraine JSIC. The object of the research is the insurance company INGO Ukraine JSIC - one of the leading financial institutions in Ukraine with great experience and powerful staffing potential. The subject of the study is the insurance portfolio as a tool to ensure the reliability of the insurance company. The article describes the theoretical approaches of the role of the insurance portfolio in ensuring financial stability of the insurance company. An analytical estimation of the structure of the insurance portfolio of INGO Ukraine JSIC was conducted. The general insurance portfolio is analysed, and the assessment of its balance is given as well. The methodical approaches to the analysis of the insurance portfolio were investigated, which enabled asserting that the analysis of the insurance portfolio was reduced to the analysis of the stability of insurance operations and the problem of the formation of a balanced portfolio of the insurer, which requires consideration of the insurance risk according to its insurance grade and the degree of likelihood of damage occurrence. Thus, the most important task of management in insurance is the formation of a rational insurance portfolio, since at this stage the results of the follow-up activities are laid.

Keywords: insurance company; insurance premiums and payments; insurance; receipt; risks. 